$36 \mid$\begin{tabular}{l|} 
ウラン鉱床の分類 \\
F.J. Dahlkamp: Classification of \\
Uranium Deposits. (Mineral \\
Deposita 13, 83 104 (1978), \\
p. 83 104)
\end{tabular} 近年, とくに 1965 70年のウラン探鉱の ブームの時代以降, ウラン鉱床について多 数の新しいデータが蓄積されてきた。現在 その鉱床分類の見直しと再構築が行われる べき時にきている。しかし，本論文で触れ るのは, 西側世界の鉱床に限定されたもの である。全般的にいつてウラン鉱床は，そ の成因はすぐれて地質的環境に関係してい るらしい。

すなわち時代とか構造に対して高度に選 好性が強いと考えられる。抽象的にいつて ウラン鉱床はつぎの 3 つに分類することが できよう。第一に，一次的に内成因的作用 によつて生じたもの，第二に一次成因のも のから外成因的作用により二次的に生成し たもの，第三は第三紀のものである。

これは内成因的変成作用によつて生じた と考えられる。しかしながらこの変成作用 の間に㧍けるウランの挙動についてはほと んど知られていない。時代については，つ ぎの 3 つの時期があげられる。

第一に, 後期始生代一初期原生代, 第二 にヘルシニアン造山期, 第三に後期原生代 である。具体的にいつてウラン鉱床は, 母 岩, 年代, 構造などによつて19の型に分け られるがこのうち経済的な意義を有するの は 6 種類である。これを優劣の順にあげる とつぎのようになる。

砂岩型》磁岩型, 迸入岩体中に内在する 型, 疑似釷脈型》熱水性釷脈型, calcrete 型。このほかに将来の潜在的な資源として 鉱量は莫大であるが低品位 (10 数 100ppm) な資源として黒色頁岩 (Kolm/スウェーデン, chat ternooga/アメリカ合衆国, 韓国, キュ 一バ)燐酸塩鉣床（モロッコ, アンゴラ, フロリダ/アメリカ合衆国) 褐炭 (ダコタ /アメリカ合衆国) などがあげられよう。

\section{1. 砂岩型}

Peneconcordant型, Roll型, TectoLithologic 型などの亜型に分けられる。い ずれも後生的なものである。第一のは岩相 規制の強いもので主として第三紀, ジュラ 紀, 三畳紀，石炭紀などに見出される。コ ロラド高原, ニューメキシコ州のChurchrock地区, ニジェールのAgades地区, ア
ルゼンチンの Sub-Andean帯, 南部オース トラリアのLake Frome embaymentなどの 例があげられる。第二のは酸化された地下 水によるもので主として第三紀（ワイオミ ング, テキサス)の例があげられるがユタ， コロラドではジュラ紀に属している。第三 のは, 断層帯に沿つて形成されたもので, その時期は, 三畳紀, ジュラ紀, 早期から 中期にかけての原生代などがあげられる。

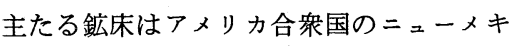
シコにある。

\section{2. 磁岩型}

22 億年より古い早期原生代/後期始生代 の地層中にのみ経済的なものが存在する。

地理的には 2 つの地域があげられる。a) カナダのオンタリオ州B1 ind River, Elliot Lake, b) 南乃のWitwater srand, Orange Free State。成因については定説はないが おそらくウラン鉱物が重鉱物として同生的 に沈積したものであろう。しかしそれには 現在では地球上に存在しない非酸化ないし 低酸化気圏を想定せねばならない。

\section{3. 迸入岩体中に内在する型}

経済的に価值があるのは, 南西アフリカ のRoessing のもののみが知られている。

ここでは鉱床はAlaski te 中に鉱染状に 存在する。時代は後期原生代である。この ほかカーボナータイト, 石英閃緑岩中のも のなどが知られている。

\section{4. 疑似鉱眽型}

塊状鉱脈又は変性堆積岩/結晶片岩など の破砕帯中に鉱染するものである。時期は 2 つに限定される。a）カナダ, オースト ラリアのものを含めて大部分は下部原生代 の岩石中に存在する。（Rum Jungle， Alligator River/オーストラリア, Athabasca, Beaverlodge地域/カナダ） b) その他の, フランス, ポルトガル, スペインなどのも のはヘルシニアン造山帯 (後期石炭紀 早 期二畳紀 ) 中にある。成因は，あるものは supergene としている。 しかし, 初生鉱床から 移動し再沈殿したとす る説が有力である。

5. 熱水性鉱眽型 岩漿成因のものであ り, 多金属高温性のも のでウランはUraninite として存在するものと Pitchblendeの単一鉱 物として存在するもの がある。年代的には， ヘルシニアン期, 後期
原生代，Larmide期などがある。西側諸国 に経済的なものは知られていないがソビェ ト連邦, ルーマニアなどにこの種のものが 知られている。インドの Jaduguda 鉱床も これに属している。

6. Calcrete型

乾燥気候地域では, ウランは, 始生代の 花崗岩質基般岩中に切られた平坦なチャン ネルの中に不規則レンズ状の形に濃集して いる。粘土, 砂やCalcrete (=Caliche) がおちこんで充媜している。ただひとつオ 一ストラリアのYeelirrieに経済的なもの が知られている。鉱床は, 表面近いところ に存在している。（北大 牛沢信人）

\section{7 三軸圧縮における岩石強度决 定法の提案 \\ U.W. Vogler and K. Kovari: Suggested Methods for Determin- ing the Strength of Rock Materials in Triaxial Compression (Int. J. Rock Mech. Min. Sci. \& Geomech. Abstr., Vol. 15 (1978), p. 47 51)}

本文は, ISRMの標準委員会における一 連の試験法標準化の一つとして, 各専門委 員によつてまとめられた標準試験法の提案 である。

この試験法においては, 三軸圧縮をうけ る円柱岩石供試体の压縮強さを計測し, 封 圧一圧縮強さのプロットにより得られた強 度包絡線より内部摩擦角 $\phi$, 見かけ粘着力 $c$ を算出する。本文中では, この試験にお ける装置, 供試体, 試験手法, 物性值算出 および結果報告についての基準が提案され ている。

例光ば，供試体について次のようら標準 が提案されている。供試体の高さと直径の 比は $2 \sim 3$ 以内とし, 径は最大粒径の 10 倍 以上とする。端面は $0.02 \mathrm{~mm}$ 以内の平面と し, 供試体の縦軸に対する垂直方向と 0.001 ラジアン以内または $1 / 1,000$ 以内の

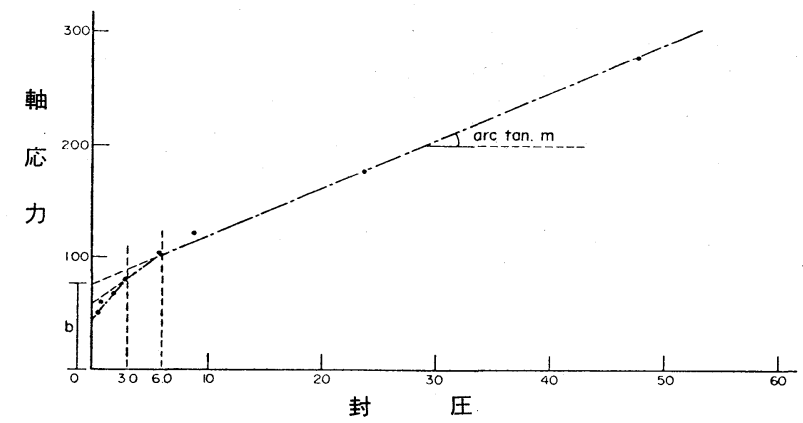

第 $37 \cdot 1$ 図 三軸圧縮における強度包絡線 
直角度とする。側面は $0.3 \mathrm{~mm}$ 以内の直線と する。また, 試料は, 供試体準備まで自然 含有水を保つように 30 日以上保管しない。

試験手法について次のような基準が提案 されている。球面座の使用と載荷軸をそろ えること。軸荷重と封圧は, 垂直応力と側 面への応力がほぼ等しいように同時に増加 させる。軸荷重は $0.5 \sim 1.0 \mathrm{MPa} / \mathrm{s}$ の定荷 重速度で連続的に増加せしめ, 5 15 分間 内に破壞に至るようにする。以上の他, 装 置, 供試体および試験手法について詳細に 標準化されている。

物性値の計算として, 王縮強さは試験中 の最大軸荷重と最初の供試体断面積より計 算する。異なる供試体によつて得られた封 圧と相応する压縮強さを第 $37 \cdot 1$ 四のよう にプロットする。図中の各点より, 適当な 直線の連続として強度包絡線を描く。図中 の各々の直線について勾配 $m$ と縦軸方向

（圧縮強さ）の間隔 $b$ を得, クーロンの破 壊理論により内部摩擦角 $\phi$, 見かけ粘着力 cを算出する。

$$
\begin{aligned}
& \phi=\operatorname{arc} \sin ((m-1) /(m+1)) \\
& c=b(1-\sin \phi) / 2 \cos \phi
\end{aligned}
$$

結果の報告として次の事項を記載する。

(a) 岩石学的記述

（b）異方性, 層理, 葉片状層などに対す る供試体載荷軸の方向

(c) 試料採取の地質学的地域, 深さ, 方 向や採集資料および方法。試料保存の経過 と䨌囲気

（d）含水比, 飽和度

（e）試験経過時間または荷重速度

（f）試験の資料として, 試験機, 三軸セ ル，封圧載荷および計測装置の説明

(g) 供試体数

（h）他の観察事項として, 破壊のモード や単位体積重量, 空隙率などとそれらの決 定法

（i）供試体番号による表として, 供試体 の高さ, 径および試験における封圧と相応 する圧縮強さ

（j）圧縮強さと封圧の関係をプロットし 強度包絡線を示す図

（k）異なる封圧の值に対して算出された 内部摩擦角 $\phi$, 見かけ粘着力 $c$ を示す表

以上における岩石学的記述, 試料保存な どについて別途基準が提案されている。

（公資研 小杉昌幸・高多 明 )

38

実験室実験による安価なレイズ ボーラの掘削費用の見積り法

G.L. Dollinger: Lab Tests Provide Low-cost Method for Predicting Raise Boring Costs. (E/MJ, Vol. 179 , No. 1 (1978) p. $86 \sim 89$ )

レイズボーラ(掘上りボーリング機械)の掘削 費用は，カッ夕にかかる費用に大きく依存する。 したがって, カッタの選択に当っては, 掘削速
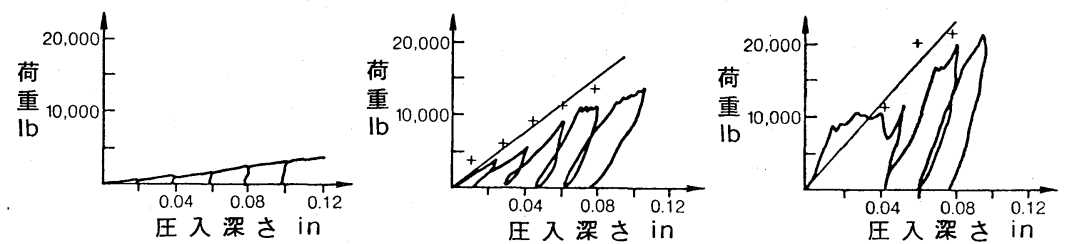

1）軟岩（塑性）中硬岩（弾性）

第 $38 \cdot 1$ 図ビット荷重・圧入深さ曲線

度や寿命を考慮して, 掘削能率が高まるよう にしなければならない。過去カッタの設計や選 択は，掘削予定地域の地質や岩質の調査，付 近の鉱山やトンネルで得たデータをもとに 行なつていたが, 実際の掘上り掘削の環境 条件を満たした実験室実験により掘削速度 やカッタの寿命を見積る方法が最も簡便で かつ安価である。

\section{ビットの压入試験}

直径 $6 \mathrm{~cm}$ 以上の試料岩石を直径 $11.4 \mathrm{~cm}$ の鉄製円筒に入れ “Hydrostone Super X” でかため, これに $1.3 \mathrm{~cm}$ 径の円すい形ビ , トを压入した。このときのビットに与えた 荷重と圧入深さを測定して, ビット荷重一 王入深さ曲線を求めるとともに, これらの データを電算機に入れた。第 $38 \cdot 1$ 図 1) は頁岩, チョークなどの軟岩, 2) は粗粒 石灰岩, 砂岩などの中硬岩, 3 ) は片麻岩, けい岩などの硬岩に対するビット荷重・圧 入深さ曲線の記録例である。この図からわ かるように, ビットの圧入により, 軟岩に ついては破壊片がはく離せずに粉化し，中 硬岩については，大きい破壊片が生ずるが， これによつて荷重の減少を伴わず，また硬 岩については，小さな破壊片がはく離する と同時に荷重も大きく減少している。

\section{掘削速度とカッ夕の費用の推定}

ビットの岩石に対する圧入実験により史 際の掘上り掘削速度を推定した。第 $38 \cdot 1$ 困に示すようなビット荷重・圧入深さ曲線 のビットの圧入深さが $0 \sim 0.25 \mathrm{~cm}$ の範囲 を最小 2 乗法により直線で近似し(第38.1 図 2）3）参照）ビットを岩石に単位深さだ け圧入するに必要ビット荷重を求め, これ を岩石の圧入指標 $(\mathrm{kg} / \mathrm{cm})$ と称した。こ の值は, 軟岩では 17,700 , 中硬岩では $17,700 \sim 31,000$, 硬岩では 31,000 以上で あつた。掘削速度の推定は, 実際のビット も圧入実験におけると同じ挙動をすると仮 定して, 上記の値から直接行なつた。例え ば, レイズボーラの掘削へッドの各ビット に $5,000 \mathrm{~kg}$ の荷重がかかると仮定し, さら に岩石の圧入指標を $20,000 \mathrm{~kg} / \mathrm{cm}$ とする と, ビットが岩石に接触するごとに， 0.25 $\mathrm{cm}$ 貫入することになる。ここで，掘削一 ッドの回転数が与えられると, 掘削速度が 計算できるが, この回転数はレーズボーラ

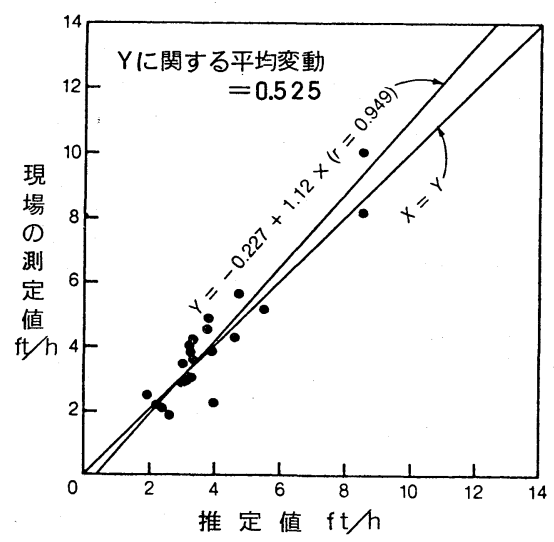

第38·2図 レイズボーラの掘削速度の推 定値と現場の測定值との比較

本体の能力やドリルロッド径などから決定 される。

カッタの費用は, カッタの寿命から直接 求められるが，カッタ寿命は岩石の圧入指 標, 実際のカッタの破損率やカッタの直径 などに関係する。過去の経験から上記のよ うにして推定した掘削速度とカッタの寿命 はひかえめで, 現場では推定值より掘削速 度は速く,カッタ寿命は長くなつている。 この差異は, 実験室で使用する岩石では現 場の岩石のき裂や節理の影響を考慮できな いためである。しかし，これらにもかかわ らず，第 $38 \cdot 2$ 図に示すように掘削速度の 推定値と現場の值との差異は $15 \%$ 以内で あつた。また, カッタの寿命の推定值も摩 耗性の大きい岩石に対して実際の寿命の $15 \%$ 以内であつた。

\section{電算機による現場掘削の推定}

レイズボーラの回転数を毎分 10 回転, 掘 削へッド直径 $2.4 \mathrm{~m}$, ロッド径 $25 \mathrm{~cm}$, 掘上り 距離 $188 \mathrm{~m}$, 岩石の圧入指標 $35,000 \mathrm{~kg} / \mathrm{cm}$ として電算機により，現場掘削を推定した。 まず，カッタへッドガスムーズに回転する ために, へッドにかかる垂直力に対する水 平力の比は 0.08 とした。カッタにかかる力 は $15.75 \mathrm{t}$ ，掘削速度は $1.04 \mathrm{~m} / \mathrm{h}$, カッタの 平均寿命は $213.5 \mathrm{~m}$, カッタの価格は 1977 年 8 月 15 日本船渡し価格でm当り 227.7 ドルとなつた。

(公資研 㴻川道雄) 

型X線マイクロアナライザの 有用性

Evrard, L. et De Cuyper, J.: La Microsonde Quantitative à Balayage Comme Méthode d'Investigation en Minéralurgie. (Industrie Minérale,"Minéralurgie" Mars (1978) p. $2 \sim 6$ )

走査型 $\mathrm{X}$ 線マイクロアナライザが，選鉱 の研究に極めて有用であることを示す $4 つ$ の研究の事例が，以下のように報告されて いる。

\section{（1）鉊一亜鉛の硫化鉱}

この鉱石は, 閃要鉛鉱, 方鉛鉱, 磁硫鉄 鉱，黄鉄鉱および少量の黄銅鉱が珪酸質脈 石中に存在する組織をもつ。鏡下で閃亜鉛 鉱は，その構造中に異常に高い比率で鉄を 含有することを示唆する光学性を呈する。 閃亜鉛鉱が，マーマタイト $(\mathrm{Zn}, \mathrm{Fe}) \mathrm{S}$ の 形で多量の $\mathrm{Fe}$ を固溶しうることは周知の通 クである。

この鉣石の場合，近似の組成の標準物質 を使用しつつ実施したマイクロアナライザ 分析によれば，閃要鉛鉱中の鉄分は比較的 均一に分布することが示され，測定された 平均品位はZn $54.74 \%, \mathrm{Fe} 11.73 \%, \mathrm{~S} 32.98$ \%であつた。これは $18 \%$ 余の $\mathrm{FeS}$ が, 閃亜 鉛鉱に溶け込んでいることを意味する。

上記のことがらと，閃亜鉛鉱中にかなり 小さな磁硫鉄鉱・黄鉄鉱の離溶組織が存在 することとを考え併せると，Zn 品位 50 \% 以上の精鉱の回収を意眓するのが無理なこ とは明らかである。

選鉱試験の結果，上記の予測が立証され た。

\section{（2）銅一鉛一亜鉛の複雃硫化鉱}

黄銅鉱，方鉛鉱，閃亜鉛鉱，黄鉄鉱打よ び硫砣鉄鉱で構成されるこの鉱石は，さら に四面銅鉱 (この鉱物の単純化した化学式 は $\left.\mathrm{Cu}_{12} \mathrm{Sb}_{4} \mathrm{~S}_{3}\right)$ の形で，相当多量の銅を含 有していた。

研究試料中に四面銅鉱が多量に存在した ので，第 1 は黄銅鉱および四面銅鉱として 存在する銅の割合，第 2 は四面銅鉱に固溶

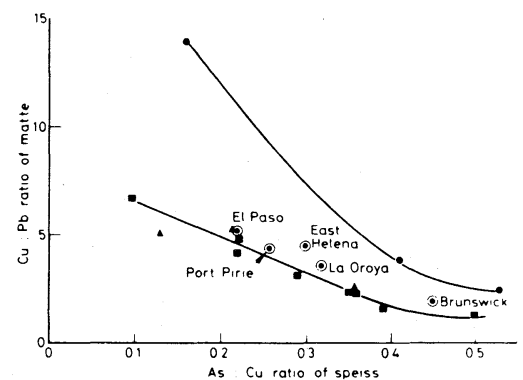

- $1000^{\circ} \mathrm{C} \backsim 1150^{\circ} \mathrm{C}: \bullet 9 \%$ Na in matte, $1000^{\circ} \mathrm{C}$. $\cdots$ industrial dato

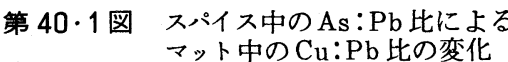

する亜鉛の割合を決定することに興味がも たれた。

この課題は, 四面銅鉱の平均化学組成を 知る目的で鉱石研磨面をマイクロアナライ ザ分析に供すること，および湿式分析のデ ータに基づいて測定値を再計算することに より，迅速に解明できた。

\section{（3）含金焙焼黄鉄鉱}

主として黄鉄鉱からなるこの鉱石におい て，黄鉄鉱中に金が超顕微鏡的包有物（1 $\mu$ 以下) として存在し, まれには光学顕微 鏡で観察することもできる。したがつてこ の鉱石は，青化法で金を回収するのに適さ ず，黄鉄鉱の焙焼後も同様であることが明 らかである。

焙焼黄鉄鉱および青化浸出残渣の走査型 マイクロアナライザによる検査は, 金の多 くが銀一金合金の形態で銀中に存在するこ とを実際に示した。その上，焙焼プロセス はより観察しやすい粒子の形で，金のセグ リゲーションをひき起こしたことが明りよ うとなつた。この現象は，すでに多くの著 者により指摘されている。

ミクロンオーダーで粒状化し, 黄鉄鉱の 焙焼で生成した赤鉄鉱の空隌を構成してい る細かい溝の内面に位置するこの金一銀合 金は，青化法に不向きであることを示して いる。

（4）銅電解アノードスライムの構成成分 の研究

これは銅電解中に生成するアノードスラ イム中の，セレンとテルルの分布に関する 研究である。

これらのスライムが極めて微粒なため ( $60 \%$ 以上が $10 \mu$ 以下), 光学顕微鏡では 研究が困難である。マイクロアナライザを 用いての分析により，次のことが判明した。

銅分が高い試料においては，セレンは銅 および銀と結合したり，銅だけと結合して， $\mathrm{CuAg} \mathrm{Se}$ または $\mathrm{Cu}_{x} \mathrm{Se}(x$ は 2 に近い)を 形づくる。一方テルルは, $\mathrm{Cu}_{2} \mathrm{Te}$ や $\mathrm{Ag}_{2} \mathrm{Te}$ のような単純テルル化物の形では観察され ず, $\mathrm{CaAg}(\mathrm{Se}, \mathrm{S}, \mathrm{Te})$ および $\mathrm{Cu}_{x}(\mathrm{Se}$,

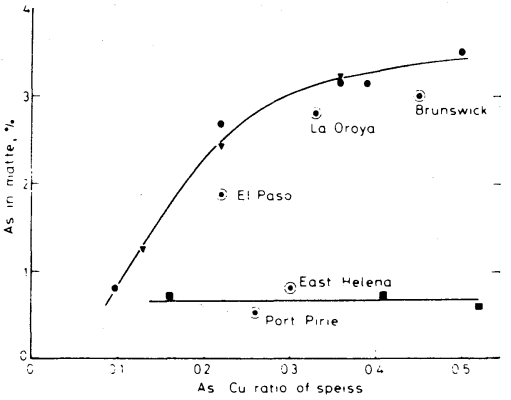

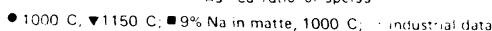

第 $40 \cdot 2$ 図 スパイス中の $\mathrm{As}: \mathrm{Cu}$ 比による マットへのヒ素の溶解度の変化
$\mathrm{S}, \mathrm{Te}$ ) のタイプの化合物中に固溶体の状 態で結合しているように認められる。この 同形置換は, Teが5\%を超光ない範囲で変 動性に富むことがわかつた。

銅分の低い試料においては，七レンは $\mathrm{Ag}_{2} \mathrm{Se}$ にかなり近い組成の化合物中に存在 する。テルルと硫黄は，そこでも固塎体の 状態で含有される。（早大 原田種臣）

\section{0 含銅鉛ドロス製錬に関する基 礎的研究 \\ A.G. Matyas.: Metallurgy of Lead-Copper Dross Smelting. (Trans. Inst. Min. Metall., section C, Vol. 86 (1977), c $190 \sim 194$ )}

溶鉱炬から出た粗鉛中の銅は，一般に脱 銅過程で得られるドロスから回収される。 ドロス製鍊の基礎として, 溶融鉛一スパイ スーマットの 3 相に分離する $\mathrm{Pb}-\mathrm{Cu}-\mathrm{As}$ - $\mathrm{S}$ 系の平衡関係, およびこの 4 元系にア ンチモンまたはナトリウムを添加した時の 平衡関係への影響について研究をおこない， 生成される各相間の組成の相違から，実際 製鍊への応用について主に考察している。

脱銅ドロスの溶鍊は，その以後の処理に 適した形にするため銅をマット，スパイス に濃縮し，さらにできるだけ鉛を溶解しな いようにすることが目的であることから， 生成するマットとスパイス中の $\mathrm{Cu}: \mathrm{Pb}$ 比 を可能な限り大きくすることが望ましい。

第 $40 \cdot 1$ 図に示すごとく，スパイス中の $\mathrm{As}: \mathrm{Cu}$ 比が小さくなると，すなわち匕素 が少なくなるとマット中の $\mathrm{Cu}: \mathrm{Pb}$ 比は大 きくなる。アンチモンも七素と同様の影響 をおよぼすが，七素と比較するとその作用 は小さい。しかし実操業のマットは全体的

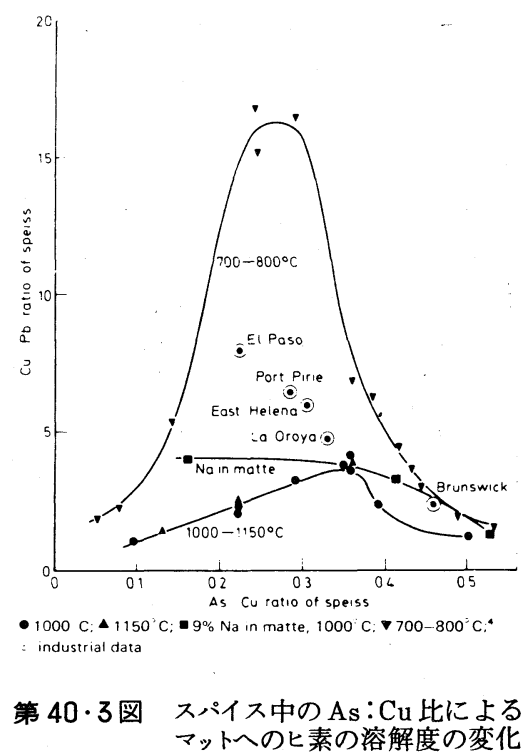


にわずかながら大きな値を示している。そ こで実際のマット組成に近づけるために $\mathrm{Na}_{2} \mathrm{~S}$ の形でナトリウムを添加したところ, マット中の $\mathrm{Cu}: \mathrm{Pb}$ は添加しない場合に比 較すると約 2 倍となり, 平衡関係へのナト リウムの影響の大きいことがわかる。しか し実験をおこなつた $1000^{\circ} \sim 1150^{\circ}$ Cの温度 差による平衡関係への影響は認められなか つた。

一方，マットへの七素の溶解は第 $40 \cdot 2$ 図に示すように，スパイス中の七素の増加 によりマット中の七素量も増大する。しか
しマット中にナトリウムが存在すると，七 素の増加は認められず, いくつか報告され ているヒ素量の低い実操業のマットについ ての現象を説明することができる。

スパイスは銅の原料として使用されるこ とから, $\mathrm{Cu}: \mathrm{Pb}$ 比を大きくすることが望 ましい。第 $40 \cdot 3$ 図に示したように 1000 $\sim 1150^{\circ} \mathrm{C}$ ではスパイス中の $\mathrm{As}: \mathrm{Cu}$ 比が 0.35 でスパイス中の $\mathrm{Cu}: \mathrm{Pb}$ 比が最大值の 4 を示し, さらにマット中にナトリウムが 存在すると大きくなる傾向にある。しかし 温度によりスパイスへの鉛の溶解度が大き
く変化し， $700 \sim 800^{\circ} \mathrm{C}$ では $\mathrm{Cu}: \mathrm{Pb}$ 比が最 大值で 16 となる。以上のことから,ドロス 製鍊ではスパイス中のCu：As 比を大略 4 になるように調整し，スパイスをその液相 線温度よりもわずかに高い温度を保ち,さ らにナトリウムを添加することにより，ス パイスへ銅を集め, 鉛の溶解度を低くする という効果が期待される。さらに，ナトリ ウムの存在は鉛相に溶解する七素, 硫黄, 銅の量を低くする効果も認められた。

（東北大 日野光久.阿座上竹四）

\section{本会記事}

\section{$\diamond$ 委 員 会 $\diamond$}

○長期計画委員会 (53.8.2) 出席者：房 村委員長他 15 名 事務局: 須田・松村 議事：1）委員長挨拶とこれまでの検討経 過報告-2）検討項目の説明（須田事務局 長） 3）討議：(1)会員制度の検討, (2)専 門委員会制度復活の検討

○有価金属のインプレース・リーチング技 術研究特別委員会 (53.8.9) 出席者：伊 藤一郎委員長他 11 名 議事：1）委員会 経過報告 (委員長) (1)委員会研究成果の総 括，(2)通産省委託インプレース・リーチン グ技術調査の成果について, (3)前回の議事 経緯 2) 本年度の研究組織 3）討議 …… 以上午前中実施, 午後から第 1 , 第 2 , 第 3 小委員会を開催。議事内容はいず れも「今後の研究の進め方について検討」。 ○日本・ポーランド技術交流委員会 (53.8. 11 ) 出席者産山口梅太郎委員長他 13 名 事務局：清水 議事：1）ポーランドグル ープの受入費用の概算見込について 2) ポーランドグループの国内滞在スケジュー ルについて 3）ポーランド訪問日本人グ ループよりのポーランドの事情聴取 4) その他

○長期計画小委員会 ( 53.8.18) 出席者: 穂積重友小委員長他 3 名 事務局: 須田 . 松村 議事：1）本委員会議事録確認 2) 会員制度の検討 (免除会員, 休会制度)

3）専門委員会の設置について O Joint Meeting MMIJ-A IME 1980 準備委員会製鍊小委員会 (53.8.21) 出席者: 池田陽次郎小委員長他 5 名 事務 局：須田 議事：1）製鍊 Sessionの検討 2) その他

○編集企画・経費小委員会 (53.8.21) 出 席者：石原透小委員長他 4 名 事務局: 須 田 議事：1）10 項目 の節約を数字を上 げて検討 2) その他

O Joint Meeting MMIJ-AIME
1980 準備委員会採鉱・石炭小委員会（53. 8. 22 ）出席者：岩崎孝小委員長他 8 名 事務局：須田 議事：採鉱・石炭Session の検討

○海底漂砂鉱床の探査之開発技術研究特別 委員会 (53.8.23) 出席者: 伊藤福夫委員 長他 16 名 議事：1）バイブロコアラに ついての勉強会 2) 電動小型バイブロコ アラの仕様検討 3）その他

OJoint Meeting MMIJ-AIME 1980 準備委員会鉱床・探査小委員会 $(53$. 8. 26 ）出席者: 大塚良平小委員長他 5 名 事務局：松村 議事：鈗床・探査 Session の検討

O Joint Meeting MMIJ-AIME

1980 準備委員会選鉱小委員会（53.8.28） 出席者：原田種臣委員長他 6 名 事務局： 須田 議事：選鉱 Session の検討 OJoint Meeting MMIJ-AIME 1980 準備委員会（53.8.28）出席者： 後藤佐吉委員長他 22 名 事務局: 須田 · 松村 議事：1）前回議事録確認 2）大 会会場の検討 3) 大会日時の検討 4) 小委員会の設置と小委員長の選出 5) Technical Sessionの検討

\section{$\bowtie$ 支部だより}

\section{・・関 西 支 部 $・ \bullet$}

\section{講演会}

講 師：オーストラリア国ニューサウスウ ェルズ大学講師 K. R. VOST氏

題 目: 諸外国における坑内温度問題の研 究情況, その他について

日 時： 53 年 6 月 26 日 (月) $13.00 \sim 15.00$

会 場: 京都大学工学部資源工学教室会議 室

出席者：約 30 名

内 容

VOST 氏はニューサウスウェルズ大学で 物理学の講義をするとともに, 坑内温度問
題に関する研究をされているが，昨年から 本年にかけて休睱を利用し，南アフリカの チャンバーオブマインズ鉱山研究所, 次い で英国のノッティンガム大学で合計 8 カ月 間研究した後来日し，4月中旬から 6 月末 まで京都大学工学部招へい外国人学者とし て資源工学教室で研究生活を送られた。日 本鉱業会関西支部ではこの機会に上記の題 目で講演を願つた。その内容は次のようで ある。

まず，オーストラリア国 Broken Hi 11鉱 山をはじめオーストラリアの鉱業事情と同 国の珍しい風土について述べ，次に南アフ リカ共和国での鉱業事情について説明した。 すなわち, この国の主なる研究問題は(1)金 山の採掘の機械化, (2)山はね対策, (3)坑内 温度問題などであることを指摘し, これら について解説し, 特に温度問題について詳 しく説明した。金山の最深部では深さが $3,500 \mathrm{~m}$, 岩盤温度は $53^{\circ} \mathrm{C}$ になつていて, ポテンシャルェネルギーだけによつても $14^{\circ} \mathrm{C}$ も温度が上昇するはずであり, このた め約 $1 / 3$ の金山で泠却機を使用しているとの ことである。英国の炭鉱の温度問題として は, 地熱よりむしろ機械熱による温度上昇 であることを明らかにし, 同氏はその周期 性と遅れについて研究していることを述べ た。最後に, 日本で豊羽鉱山および三池鉱 業所を見学したときの印象を述べ, とくに 豊羽の冷却技術の水準が高いのに感心した こと, そのほか日本の風土の綺麗なことや 風俗習慣の優れている点などを指摘した。

( 斎藤敏明 )

Leoben 鉱業大学鉱物探査大学院研修 コースの参加者募集について

。期間：1979年 2 月 1 日〜 6 月 30 日

。主催：オーストリア共和国コネスコ

。コースの使用言語 : 英語

○年令：35 才以下 。授業料：無料

○中込締切：1978 年 10 月 31 日

。申込先：日本国オーストリア大使館

関心を㧍持ちの方は, 至急本会までご連 絡下さい。 